\title{
МОДЕРНІЗАЦІЯ ОБПРИСКУВАЧА ОП-200О ДЛЯ ЗАХИСТУ НАСАДЖЕНЬ СМОРОДИНИ ЧОРНОЇ ПРОТИ СИСНИХ ШКІДНИКІВ
}

\author{
Бакалова Алла Володимирівна \\ кандидат сільськогосподарських культур, доцент \\ Поліський національний університет, м. Житомир, Україна \\ ORCID: 0000-0002-6803-6304 \\ bakalova1970@ukr.net \\ Грицюк Наталя Вікторівна \\ кандидат сільськогосподарських культур, доцент \\ Поліський національний університет, м. Житомир, Україна \\ ORCID: 0000-0002-4185-7495 \\ ngritsyuk78@gmail.com
}

Титаренко Володимир Євгенійович

Кандидат технічних наук, доцент

Державний університет «Житомирська політехніка», м. Житомир, Україна

ORCID: 0000-0002-4518-1808

Voldtit@gmail.com

\begin{abstract}
Завдяки смаковим, дієтичним, вітамінним і споживчим якостями смородина чорна є досить поширена у багатьох господарствах та на присадибних ділянках. Але на жаль, як і багато інших культур, схильна до ураження хворобами і пошкодження шкідниками, особливо з колючо-сисним ротовим апаратом. Тому, технологія захисту смородини чорної наразі $є$ актуальним питанням.

У статті запропоновано використання модернізованого обприскувача ОП-2000 з оновленими особливостями конструктивного спеціального рухомого складу, для кращої ефрективності обприскування кущів смородини чорної.

Нашими дослідженнями доведено, що щільність сисних фітофрагів зменшилася при обприскуванні модернізованим, оновленим ОП-2000. Відповідно зменшився коефіцієнт заселеності великої смородинової попелиці на 0,34, червоносмородинової галової попелиці на - 0,36, смородинового брунькового кліща на - 0,29 та звичайного павутинного кліша на - 0,23 одиниці, порівняно з використанням штангового обприскувача ОП-2000.

Встановлено, що зменшення чисельності сисних шкідників на рослинах смородини чорної позитивно вплинуло на формування ягід, та збільшення маси 1000 ягід, маси ягід з куща, що підвищило урожайність на 2,9 m/2а порівняно з контрольним варіантом і на 0,6 m/2а порівняно з варіантом, де застосовували штанговий обприскувач. Використання пристрою спеціального рухомого складу для модернізації обприскувача ОП-2000 забезпечило підвищення економічної ефрективності. Так, чистий прибуток при застосуванні обприскувачів ОП-2000 становив 63459-69587 грн./га, рентабельність 350-362 \%. При використанні модернізованого обприскувача чистий прибуток збільшився на 6128 гривень з гектара, рентабельність врожаю - на 12 \% порівняно з використанням штангового обприскувача.

Дані досліджень, щодо створення спеціального рухомого складу (СРC) проводилося вперше і можуть мати продовження при подальшому вдосконалені конструкції для системи захисту ягідних культур від шкідників.

Ключові слова: смородина чорна, сисні фітофраги, вдосконалений обприскувач, показники продуктивності, спеціалізований рухомий склад.
\end{abstract}

DOI https://doi.org/10.32845/agrobio.2021.3.1

Вступ. У технологіях захисту від шкідливої біоти, механізація, так як і будь-який інший технологічний процес, відіграє важливу роль у підвищенні продуктивності праці та якості і кількості ягідної продукції у тому числі чорної смородини (Zaika, 2002; Voitiuk et al., 2005; Hoffmann et al., 2019). Наразі в Україні смородина чорна $€$ однією з поширених провідних культур не тільки на присадибних ділянках, а й у господарствах усіх фрорм власності. Ягоди смородини не тільки смачні, а й корисні, в їх склад входять вітаміни А, E, $\mathrm{B}_{1}, \mathrm{~B}_{2}, \mathrm{~B}_{5}, \mathrm{~B}_{6}$, пектини, аскорбінова кислота, яка не втрачає своїх властивостей навіть при термічній обробці. (Morocko-Bicevska et al., 2021; Bakalova et al., 2019).
Проблемою у технологіях вирощування ягід чорної смородини є недобір врожаю (30-40 \%) від сисних фітофрагів (Stepanova, 2018; Chrzanowski, et al., 2012). Тому, ефективні методи захисту рослин смородинових агроценозів від шкідників - актуальне завдання сьогодення. Для забезпечення високоякісного врожаю, в Україні при вирощуванні сільськогосподарських культур, у тому числі ягідних, пріоритетною ланкою інтегрованої системи захисту рослин $є$ застосування пестицидів. (Makova et al., 2020; El-Sayed et al., 2016). Суттєві негативні чинники, що безпосередньо впливають на урожай сільськогосподарських культур - це шкідники (Khomenko \& Slon, 2014). Механізоване обприскування у виробничих промислових 
насадженнях смородини чорної є одним з дієвіших заходів захисті від шкідливих організмів. (Bondarenko, 2017; Li et al., 2019). Отримання високих стабільних врожаїв насаджень чорної смородини проти групи сисних фітофагів, залежить насамперед, від вчасного та якісного застосування інсектицидів. (Berk et al., 2019; Pedersen, 1998). Обробка хімічними засоби захисту проти шкідливих організмів вимагають наявності високоефективної техніки (Sanchez-Hermosilla et al., 2021; Bakalova, 2020). На початкових стадіях біологічного розвитку фітофрагів проведення профрілактичних заходів захисту дає можливість зменшити їх чисельність 3 меншими нормами витрати препаратів (Broring et al., 2019; Suchkova et al., 2015). Сисні фітофаги завдають значної шкоди всім ягідним культурам, в тому числі і насадженням смородини чорної (Berk et al., 2019; Vityaz et al., 2015).

Дослідження науковців показують, що у господарствах різних форм власності в технологіях захисту рослин в більшості використовуються стандартні обприскувачі типу ОП-2000, ОПШ-3,5-24 (Україна) та ін., ці обприскувачі, порівняно, є малоефективними у системах захисту смородини від сисних шкідників (Pysarenko et al., 2017; Melnyk et al., 2013). На думку багатьох вчених, для недопущення масових спалахів сисних шкідників необхідно проводити моніторинг фітосанітарного стану насаджень смородини чорної (Duvnjak et al., 2004; Drozda \& Kocherha, 2012). За статистичними даними багатьох вчених сисні комахи під час свого живлення знаходяться під листками (Pinchuk, \& Kovalenko, 2021; Chebotok, 2019). При використанні стандартних обприскувачів нижні і середні яруси габітусу куща залишаються в зоні недосяжності хімічних речовин. Щоб вирішити цю проблематику обприскування було удосконалено штанговий оприскувач типу ОП-2000, з подальшою розробкою, на його базі, спеціалізованого рухомого складу. Для цього була забезпечена можливість бокового розпилювання робочої рідини з регулюванням її дисперсності для забезпечення оптимальних зон обприскування. Бокове розпилювання малодисперсних фрракцій забезпечує утворення «легкого туману», що стійко покриває верхні нижні та середні зони куща з об'ємним ефектом епідермісу кожного листка.

Метою роботи є розробка та визначення ефективності застосування спеціалізованого рухомого складу в системі заходів захисту смородини чорної від сисних шкідників в агроекологічних умовах Полісся України. Для досягнення поставленої мети вирішувались наступні завдання: визначення оптимальних зон розпилювання інсектицидів на кущах смородини чорної для подальшої модернізації оприскувача ОП-2000; розробка спеціалізованого рухомого складу з модернізованим оприскувачем ОП-2000 для забезпечення ефективного захисту насаджень смородини від сисних фітофрагів; дослідження ефективності застосування розробленого рухомого складу з модернізованим оприскувачем.

Матеріали і методи досліджень. Польові дослідження проводили в 2019-2021 рр. у СФГ «Надія» Черняхівського району Житомирської області та у лабораторії кафедри захисту рослин Поліського національного університету.
Ефективність пестицидів вивчали за способу обприскування рослин смородини чорної проти сисних фітофагів. Дослідження проводили на сорті Вернісаж, рослини 6-річного віку, з норма витрати робочої рідини 1000 л/га. Робочий розчин при цьому готували перед застосуванням. Моніторинг насаджень чорної смородини та облік чисельності сисними фітофагами, проводили згідно загальноприйнятих у ентомології методик. Для визначення чисельності рослин сисними шкідни-

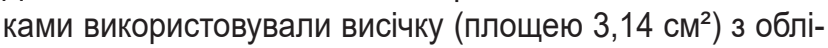
кових листків. В межах такої висічки за допомогою лупи підраховували кількість комах.

Обліки починають за появи перших листків і продовжують впродовж всієї вегетації рослин. Окомірним методом обліковували брунькового смородинового кліща за кількістю пошкоджених бруньок на кущ. Для визначення процента заселених бруньок на п'яти гілках кожного куща підраховували загальну кількість до кількість заселених кліщем бруньок.

Середню щільність фрітофагів (екз./см²) визначали за формулою 1:

$$
\mathrm{X}=\frac{\sum \mathrm{xi}}{\mathrm{S} \times \mathrm{n}}
$$

де: $\Sigma x i-$ сумарна чисельність нарахованих особин фрітофагів з усіх облікових листків, екз;

$\mathrm{S}$ - площа облікової висічки, см²;

$\mathrm{n}$ - кількість облікових листків, шт.

Площу висічки (S), зробленої за допомогою трубки, розраховували за формулою 2:

$$
\pi \mathrm{R}^{2}=3,14 \times \mathrm{R}^{2}
$$

де: R - внутрішній радіус трубки для висікання.

Обстеження заселеності рослин чорної смородини звичайним павутинним кліщем проводили з IV етапу органогенезу (початок реактивації зимуючих самиць) та періодично впродовж вегетаційного сезону.

Заселеність рослин шкідниками (\%) визначали за формулою 3:

$$
\mathrm{P}=\frac{100 \times \mathrm{n}}{\mathrm{N}},
$$

де : n - кількість заселених рослин, шт.;

$\mathrm{N}$ - загальна кількість рослин в обліку, шт.

Економічна ефективність залежить від розміру приросту врожаю та витрат на обробку культури хімічними речовинами. Основними показниками, що характеризують економічну ефективність застосування пестицидів, $€$ собівартість одиниці продукції, чистий прибуток і рівень рентабельності. Економічну ефективність підраховували методом співвідношення вартості отриманої додаткової продукції до всіх витрат на проведення заходів захисту і збирання ягід.

Результати. Системний підхід до сільськогосподарської техніки вимагає постійного відновлення та удосконалення для ефективного функціонування конструкцій агрегатів. Відновлення забезпечується високим рівнем показників ремонтопридатності конструкцій, а удосконалення можливо забезпечити шляхом їх переоснащення 
на основі використання модульного принципу заміни агрегатів.

В нашому випадку система захисту насаджень смородини чорної була покращена через удосконалення серійної моделі оприскувача ОП-2000 та створено спеціалізований рухомий склад (СРС) з його використанням. Спеціалізований рухомий склад включає силову тягову установку трактор марки МТ3-82 (Білорусь), з'єднувальний пристрій, що забезпечує маневреність і гнучкість системи, та модернізований оприскувач ОП-2000. Запропонована модернізація забезпечує більшу повноту обробки хімічним розчином ягідних кущів смородини чорної. До переваг, що забезпечуються модернізованою конструкцією, слід віднести рівномірність нанесення розчину препарату на всю поверхню листя куща смородини за рахунок мікродисперсного розпилювання.

Удосконалення конструкції оприскувача має наступні особливості:

1. Встановлені форсунки нової конструкції, що забезпечують туманоподібний ефект розпилювання розчину препарату. Форсунки закріплені на дугоподібних кронштейнах. Дугоподібні кронштейни встановлені 3 двох боків обприскувача, що забезпечує можливість одночасної односторонньої обробки двох суміжних рядів насаджень або, іншими словами, одного міжряддя.

2. Проведення оптимізації зон розпилювання розчину препарату досягнуто за рахунок моделювання геометрії дугоподібних кронштейнів та кута нахилу форсунок. Вихідними параметрами для моделювання розмірів конструктивних елементів модернізованої агрегатної установки були прийняті: відстань між рядами кущів 3000 мм; ширина агрегатної установки з модернізованим оприскувачем - 1500 мм; параметри куща смородини чорної: висота - 1200 мм, розлогість - 1200 мм.

3. Моделювання конструкцій дуг и кронштейнів (довжина 1250 мм визначена конструктивно, виходячи з середніх розмірів куща смородини чорної.)

При русі спеціалізованого агрегату в процесі обприскування насаджень смородини чорної забезпечується:

1. Кожна форсунка на дугоподібних кронштейнах виконує оптимальну обробку відповідної зони куща (верхню, середню та нижню з найбільшою заселеністю шкідників).

2. Ефект перекриття зон обприскування за рахунок геометричних особливостей установки форсунок, що визначає точку сходження потоків з певним наближенням в інтервалі 200-250 мм за середину куща.

Виходячи з таких міркувань, були визначені геометричні параметри розміщення форсунок за розрахунковою схемою. Відстань від крайніх форсунок до краю куща (а) визначається різницею ширини міжряддя по осі кущів та шириною агрегату. Дана різниця ділиться на два і від отриманого значення віднімається число 600 мм (половина ширини куща). В даному випадку розрахункове значення а = 150 мм.

Для визначення нахилу кута фрорсунки висоту AD трикутника $\mathrm{ABC}$ розраховуємо додаванням параметру перекриття (приймаємо найменше значення - 200 мм) до суми чисел: числа що визначає половину ширини куща (600 мм) та відстані «а» від фрорсунки до краю куща (150 мм). За результатом розрахунку 950 мм, використовуючи трикутник $\mathrm{ABC}$, визначаємо кут а нахилу осі форсунки відносно горизонтальної лінії, що перпендикулярна до осі симетрії спеціалізованого агрегату.

$$
A=\operatorname{arctg} B D / A D
$$

Прийнявши припущення, що BD наближено дорівнює половині дуги $L$, отримаємо кут $\alpha=33,3^{\circ}$.

Для визначення радіуса дуги (R) кронштейнів використовуємо розміри сторін $\mathrm{AB}$ і $\mathrm{AC}$, які рівні між собою, дорівнюють радіусу та складають 1137 мм (трикутник АВC).

Забезпечення обробки одного міжряддя кущів смородини за один прохід агрегату відбувається за рахунок змодельованого геометричного розміщення форсунок бокових розпилювачів, що створює дрібнодисперсне туманоподібне середовище (рис. 1). Обробка певної площі насаджень здійснюється за схемою, приведеною на рис. 2.

Оптимальність хімічної обробки забезпечується наступними параметрами та режимами:

1. Швидкість руху (1,2-1,4 км/год.) самохідного агрегату розрахована з умови забезпечення норми обприскування, яка дорівнює 800 л/га.

2. Діаметр отвору щільнового розпилювача (3,0 мм) та тиск в комунікаційній системі $(0,3-0,4$ кгс/см²) розраховані з умови забезпечення мікродисперсного розпилювання розчину препарату.

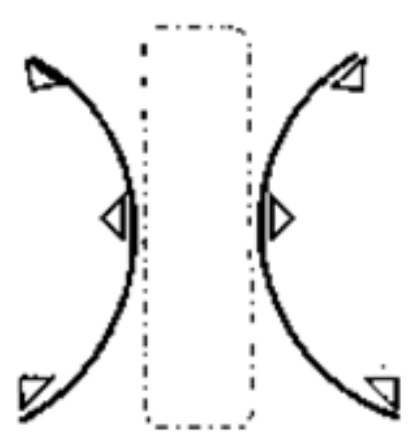

Рис. 1. Схема розміщення бокових розпилювачів на обприскувачі

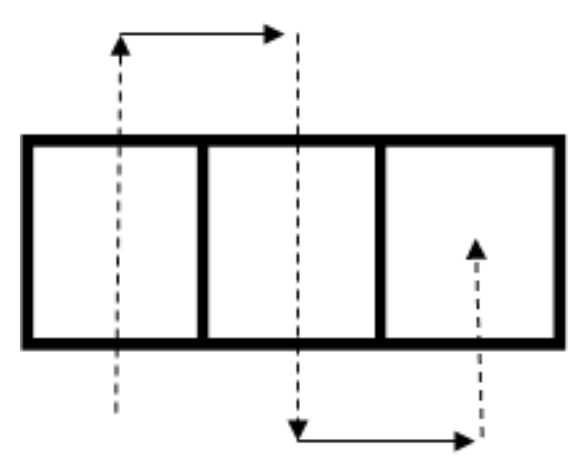

Рис. 2. Схема руху агрегату

Важливим моментом обприскування є забезпечення узгодженості наступних параметрів технологічного процесу хімічної обробки: 
- інтенсивність розпилювання;

- швидкість руху самохідного агрегату.

Практика підтвердила, що оптимальність хімічної обробки насаджень смородини чорної забезпечується швидкістю руху самохідного агрегату, яка знаходиться в інтервалі 1,2-1,4 км/год.(4-4,6 м/сек) та інтенсивністю

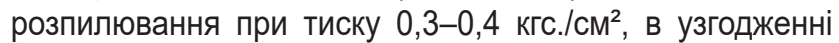
з нормою витрати робочої рідини 800 л/га.

Моніторинг заселеності сисних фрітофагів проводили на основних етапах органогенезу смородини чорної (VI, VIII, X етапи) у виробничих умовах СФГ «Надія» Житомирської області. Порівняння ефективності обприскування виконували для штангового та модернізованого обприскувача (табл. 1).

Значення сумарного коефіцієнта заселеності $\sum$ Кз змінюється від 0,56 до 2,68 залежно від варіантів досліду захисту рослин смородини чорної від сисних шкідників. Зменшення щільності шкідників за сумарним коефіцієнтом заселеності ( $\Sigma К 3)$ складає 2,2 рази при використанні штангового обприскувача ОП-2000. Застосування модернізованого обприскувача ОП-2000 зменшило чисельність великої смородинової попелиці на 15,3 коло- ній з куща; червоно смородинової галової попелиці - на 15,8 колоній з куща; смородинового брунькового кліща на 22,6 бруньок на кущ; звичайного павутинного кліща на 32,3 екземплярів на кущ, порівняно 3 контрольним варіантом.

Дослідження вирішують певною мірою актуальну проблему зменшення втрат урожайності від сисних шкідників та можуть бути використані в умовах Полісся України. Зменшення чисельності сисних фрітофагів та стимуляція росту і розвитку рослин позитивно впливає на показники структури врожаю ягід смородини чорної (рис. 3).

За результатами наших досліджень, при застосуванні різних обприскувачів, маса ягід з грона смородини чорної варіювала від 1,2 до 2,8 г. Мінімальні величини маси ягід змінювалися в інтервалі 1,2-1,8 г спостерігали у варіанті без обприскування. Ягоди розміром 1,6-2,2 г збирали при використанні штангового обприскувача. При застосуванні модернізованого обприскувача ОП - 2000 збільшилася маса ягід з грона по всіх фракціях, також збільшилася маса 1000 ягід - на 81 г та маса ягід 3 куща на 0,652 кг, порівняно з контрольним варіантом (без обприскування).

Заселеність сисними фітофрагами смородини чорної залежно від застосування обприскувачів ОП-2000

Таблиця

(2019-2021 рр.)

\begin{tabular}{|c|c|c|c|c|c|c|c|c|c|}
\hline \multirow{3}{*}{ Варіанти } & \multicolumn{8}{|c|}{ Щільність шкідників } & \multirow{3}{*}{$\Sigma K_{3}$} \\
\hline & \multicolumn{2}{|c|}{ ВCח $^{*}$} & \multicolumn{2}{|c|}{$\Gamma \Pi^{*}$} & \multicolumn{2}{|c|}{ БK$^{*}$} & \multicolumn{2}{|c|}{$3 \Pi K^{*}$} & \\
\hline & колон./кущ & Кз & колон./кущ & Кз & брун./кущ & К3 & екз./ кущ & K3 & \\
\hline $\begin{array}{c}\text { Контроль - без } \\
\text { обприсування }\end{array}$ & 18,2 & 0,66 & 19,7 & 0,68 & 28,3 & 0,65 & 38 & 0,69 & 2,68 \\
\hline $\begin{array}{c}\text { ОП-2000 } \\
\text { (штанговий) }\end{array}$ & 12,1 & 0,44 & 14,5 & 0,49 & 18,7 & 0,42 & 24 & 0,43 & 1,78 \\
\hline $\begin{array}{c}\text { ОП-2000 } \\
\text { (модернізований) }\end{array}$ & 2,9 & 0,10 & 3,9 & 0,13 & 5,7 & 0,13 & 5,7 & 0,20 & 0,56 \\
\hline
\end{tabular}

Примітка*: ВСП-велика смородинова попелиця, ГП- галова попелиця, БК - бруньковий кліщ, ЗПК - звичайний павутинний кліщ; Кз - коефріцієнт заселення; ¿Кз - сумарний коефріцієнт заселеності.

: Контроль - без обприскування ㅇП - 2000 (штанговий) ๙ ОП - 2000 (модернізований)

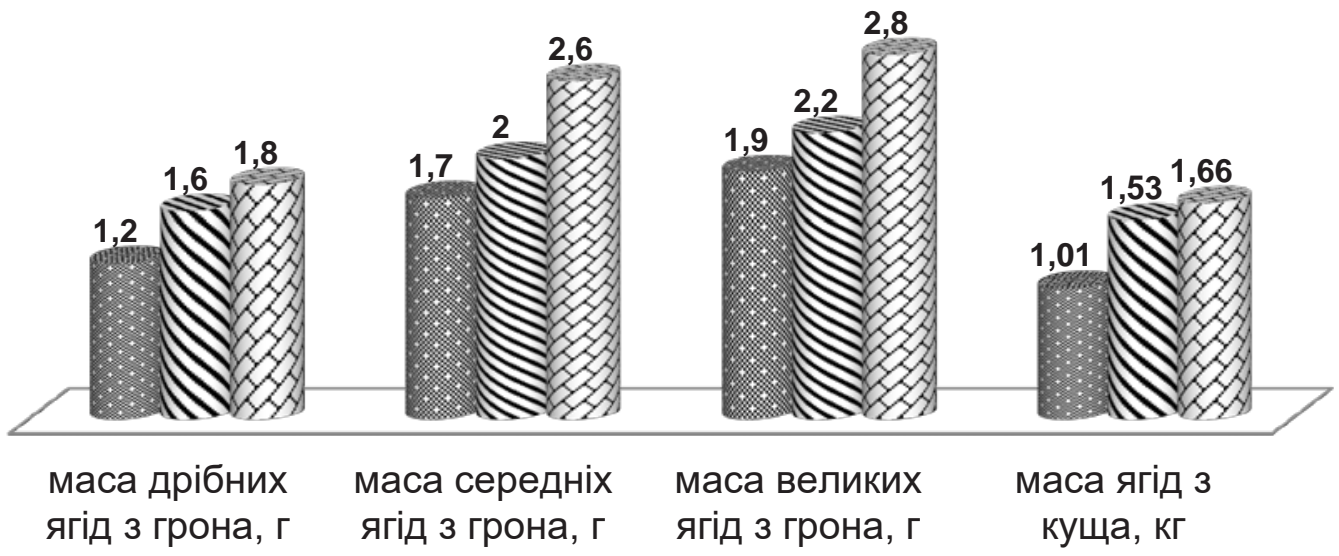

Рис. 3. Структура урожаю ягід при застосуванні різних оприскувачів на смородині чорній (2019-2021 рр.). 
Покращення елементів структури ягід смородини чорної забезпечує значне збільшення урожайності (рис. 4).

Урожайність ягід смородини чорної, при застосуванні модернізованого обприскувача ОП-2000, підвищилася на 0,6 т/га, порівняно з використанням звичайного штангового обприскувача ОП-2000 та на 2,9 т/га, порівняно з контрольним варіантом, де не використовували обприскування. Розрахунки прогнозування урожаю підтверджують достовірність результатів досліджень, оскільки найменша істотна різниця $\left(\mathrm{HIP}_{0,5}\right)$ значно менша прибавки урожаю.

Розрахунки економічної ефективності приведені в таблиці 2.

Використання спеціального рухомого складу у модернізованому обприскувачі ОП-2000 є економічно вигідним прийомом захисту насаджень смородини чорної. При обприскуванні смородини чорної модернізованим обприскувачем вартість врожаю збільшилася на 34800 грн./га, чистий прибуток - на 29618 грн./га, рентабельність - $77 \%$.

Обговорення. Підбираючи тип обприскувачів, потрібно враховувати специффіку морфологічних ознак ягідних культур та біологічні особливості шкідників (Zhidehina et al., 2017; Osokina et al., 2021). Сучасні технологічні способи реалізації захисту сільськогосподарських культури характеризуються низькою ефективність. У багатьох випадках це пов'язано з недосконалістю конструкцій для їх внесення (Munck et al., 2015). Вченими була вдосконалена технологія управління початковими параметрами цільового максимального нанесення крапель розчинів пестицидів на об'єкти обробки. При цьому сконструйовані пристрої можуть застосовуватися з широко використовуваними на практиці штанговими обприскувачами і агрегатами для обробки багаторічних насаджень. Створені механізми забезпечують максимальну інжекцію крапель форсунок розпилу розчинів, що знижує до мінімуму коагуляцію частинок рідини і в значній мірі зберігає їх число, утворене розпилювачем (Kireev \& Koval', 2018; Mitchell et al., 2011; Postolenko, 2016). Ha жаль, подібних наукових праці з обприскувачами на смородині мало, але є розробки з удосконалення обприскувачів під час обробки соняшнику. У застосовуваних технологічних процесах хімічної обробки посівів соняшнику не в повній мірі враховуються архітектурні особливості рослини, через що знижується якість обприскування у фазі розвитку 2-8 пар листків. Найбільш ефективним вважається новий спосіб нанесення розчину на рослини з урахуванням перерозподілу розчину з міжряддя на оброблювану поверхню. Для цього розроблено технічне рішення, яке дозволяє змішувати потоки робочих розчинів, спрямовані назустріч один до одного, з утворенням нового. Застосування бокового способу розпилу дозволяє при злитті перетворювати потоки розпилу від кожної форсунки в новий, більш стабільний потік, що має постійні геометричні параметри з більшою площею покриття у верхівки рослин і незмінної при коливаннях штанги обприскувача ( Borisenko et al., 2020).

Висновки. Розраховані геометричні параметри спеціальних кронштейнів для модернізації штангового обприскувача ОП-2000 (для забезпечення оптимальних зон розпилювання робочої рідини). На базі модернізованого обприскувача розроблено спеціалізований рухомий

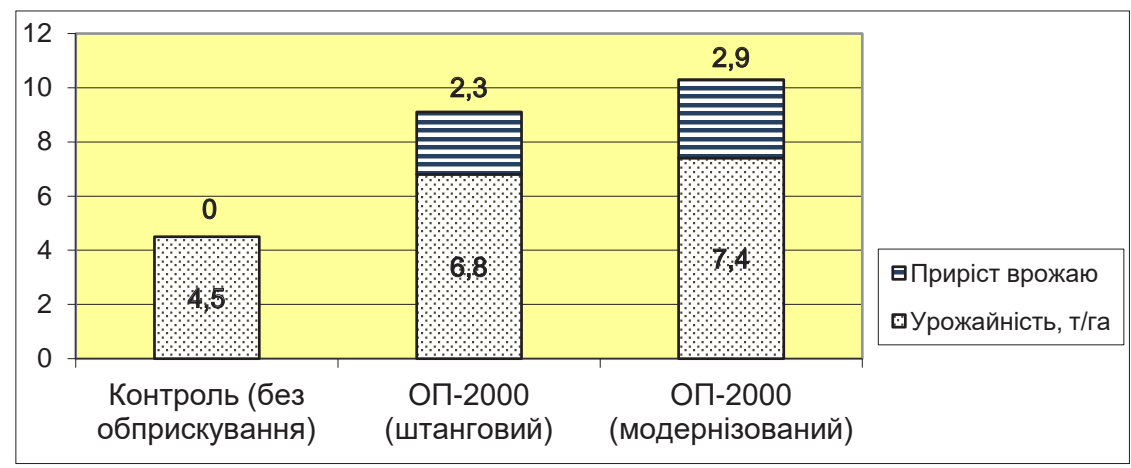

Рис. 4. Господарська ефективність при застосуванні різних оприскувачів на смородині чорній (2019-2021рр.)

Таблиця 2

Економічна ефективність застосування модернізованого оприскувача при захисті смородини чорної (2019-2021 pp.)

\begin{tabular}{|c|c|c|c|c|c|c|}
\hline № п/п & Варіант досліду & Урожайність т/га & $\begin{array}{c}\text { Вартість } \\
\text { урожаю, грн./га }\end{array}$ & $\begin{array}{c}\text { Всього } \\
\text { прямих } \\
\text { витрат, грн./га }\end{array}$ & $\begin{array}{c}\text { Чистий } \\
\text { прибуток, грн./га }\end{array}$ & $\begin{array}{c}\text { Рентабельність } \\
\text { врожаю, \% }\end{array}$ \\
\hline 1 & $\begin{array}{c}\text { Контроль без } \\
\text { обприскувача }\end{array}$ & 4,5 & 54000 & 14031 & 39969 & 285 \\
\hline 2 & ОП -2000 (штангвй) & 6,8 & 81600 & 18141 & 63459 & 350 \\
\hline 3 & $\begin{array}{c}\text { ОП-2000 } \\
\text { (модернізований) }\end{array}$ & 7,4 & 88800 & 19213 & 69587 & 362 \\
\hline
\end{tabular}


склад для ефективного обприскування чорної смородини в системі захисту від сисних фрітофагів (велика смородинова попелиця, галова попелиця, бруньковий кліщ, звичайний павутинний кліщ). Дослідження ефективності застосування розробленого спеціалізованого рухомого складу показали наступні основні результати: зменшення чисельності фотофрагів у 3,9 рази порівняно з варіантом, де застосовували штанговий обприскувач; збільшення приросту урожайності ягід смородини чорної до 2,9 т/га, що збільшує чистий прибуток від 43093 до 67666 грн./га.

\section{Бібліографрічні посилання:}

1. Bakalova, A. V., Tkalenko, H. M., Grytsiuk, N. V., Derecha, O. A. \& Shchepanivskyi, D. S. (2019). Fenolohichni osoblyvosti rozvytku smorodynovoi vuzkotiloi zlatky v nasadzhenniakh smorodyny chornoi v umovakh Polissia Ukrainy. Visnyk PDAA, 3, 65-71. doi: 10.31210/visnyk2019.03/08/ (in Ukrainian).

2. Bakalova, A. V., Grytsiuk, N. V., Stoliar, S. H., \& Tkalenko, N. M. (2020). Special aspects of the development of black currant bushes depending on weediness level in the Ukrainian Polissia. Ukrainian Journal of Ecology, 10(4), 18-22. doi: 10.15421/2020 161 (in Ukrainian).

3. Berk, P., Belsak, A., Stajnko, D., Lakota, M., Muskinja, N., Hocevar, M., \& Rakun, J. (2019). Intelligent automated system based on a fuzzy logic system for plant protection product control in orchards. International journal of agricultural and biological engineering, 12(3), 92-102. doi: 10.25165/j.ijabe.20191203.4476.

4. Bondarenko, T. V. (2017). Innovatsiinyi rozvytok yak umova efektyvnoho funktsionuvannia sadivnytskykh pidpryiemstv. Naukovyi visnyk Khersonskoho derzhavnoho universytetu. Seriia Ekonomichni nauky, 24(1), 92-96 (in Ukrainian).

5. Borisenko, I. B., Meznikova, M. V., \& Ulybina, E. I. (2020) Nauchnye aspekty tekhnicheskoj modernizacii opryskivatelej dlya himicheskoj zashchity podsolnechnika. Izvestie Nizhnenovgorodskogo agrouniversitetskogo kompleksa: nauka i vysshee professional'noe obrazovanie, 4 (60), 341-348 (in Russian). doi: 10.32786/2071-9485-2020-04-33

6. Broring, J., \& von Horsten, D. Nozzle (2019). Combinations and Arrangements for Use of a Tramline Deactivation on Field Sprayers, Gesunde pflanzen, 71, 45-49. doi: 10.1007/s10343-019-00449-7.

7. Chebotok, E.M. (2019). Dobrohot - novyiy sort smorodinyi chernoy. Sovremennoe sadovodstvo, 2, 63-68. doi: 10.24411/2312-6701-2019-10210 (in Russian).

8. Chrzanowski, G., Leszczynski, B., Czerniewicz, P., Sytykiewicz, H., Matok, H., Krzyzanowski, R., \& Sempruch, C. (2012). Effect of phenolic acids from black currant, sour cherry and walnut on grain aphid (Sitobion avenae F.) development. Crop protection, 35, 71-77. doi: 10.1016/j.cropro.2012.01.005.

9. Drozda, V. F., \& Kocherha, M. O., (2012). Zakonomirnosti funktsionuvannia ta kontrol chyselnosti kompleksu chlenystonohykh (Arthropoda) v nasadzhenniakh chornoi smorodyny (Ribes nigrum I.) za tekhnolohiiamy orhanichnoho sadivnytstva. Sadivnytstvo, 65, 144-151 (in Ukrainian).

10. Duvnjak, V., \& Banaj, D. (2004). Good professional practice in plant protection and proper use of sprayers. Actual tasks on agricultural engineering, 32, 341-346.

11. El-Sayed, A., Revell, J., Jimenez-Perez, A., Harper, A. \& Suckling, D. (2016). Identification of a floral-derived kairomone for currant clearwing, Synanthedon tipuliformis. Chemoecology, 26(5), 187-193. doi: 10.1007/s00049-016-0218-9.

12. Hoffmann, L. L., Roehrig, R., Boller, W., \& Forcelini, C. A. (2019). Deposition and coverage of soybean leaf surfaces by sprays applied using different assisted boom sprayer systems. Engenharia agricola, 39(2), 198-207. doi: 10.1590/1809-4430Eng.Agric.v39n2p198-207/2019.

13. Khomenko, I. I., \& Slon, A. S. (2014). Zakhyst chornoi smorodyny (Ribes nigrum I.) vid shkidnykiv i khvorob u zoni Lisostepu Ukrainy. Sadivnytstvo, 68, 285-289 (in Ukrainian).

14. Kireev, I. M. \& Koval', Z. M. (2018). Modernizaciya i razrabotka novyh obrazcov opryskivatelej. Agrobiznes,3, 25-29 (in Russian).

15. Li, H., He, Y.J., Qin, C.B., Liu, D. Q., \& Zhang, K. F. (2019). Ecological analysis on spray performance of multi-rotor unmanned aerial sprayer in soybean fiel. Ekoloji, 28(107), 4573-4579.

16. Makova, N. E., \& Bogdanova, O. E. (2020). Statisticheskie svoystva pokazateley rosta i plodonosheniya smorodinyi. Vestnik Krasnoyarskogo gosudarstvennogo agrarnogo universiteta, 1, 12-17 (in Russian). doi: 10.36718/1819-4036-2020-1$12-17$

17. Melnyk, O. V., \& Lychenko, I. O. (2013). Pisliazbyralnyi zakhyst chornoi smorodyny: Poliskyi dosvid, Novyny sadivnytstva, 2, 1-7 (in Ukrainian).

18. Mitchell, C., Brennan, R. M., Cross, J. V., Johnson, S. N. (2011). Arthropod pests of currant and gooseberry crops in the UK: their biology, management and future prospects, Agricultural and forest entomology, 13(3), 221-237. doi: 10.1111/j.1461-9563.2010.00513.

19. Morocko-Bicevska, I., Stalazs, A., Lacis, G., Laugale, V., Balke, I., Zulge, N., \& Strautina, S. (2021). Cecidophyopsis mites and blackcurrant reversion virus on Ribes hosts: Current scientific progress and knowledge gaps. Annals of applied biology, 8. doi: 10.1111/aab.12720.

20. Munck, I., Tanguay, P., Wehner, J., \& Villani, S.M. (2015). Impact of White Pine Blister Rust on Resistant Cultivated Ribes and Neighboring Eastern White Pine in New Hampshire, Plant disease, 99(10), 1374-1382. doi: 10.1094/PDIS12-14-1338-RE.

21. Pedersen, H. L. (1998). Field resistance of black currant cultivars (Ribes nigrum L.) to diseases and pests. Fruit varieties journal, 52(1), 6-10.

22. Osokina, N., Kostetska, K., Herasymchuk, O., Tkachenko, H., Podpriatov, H., Pusik, L., Falendysh, N., Bobel, I., \& Belinska, K. (2021). Development of temperature regime of storage of frozen black currants. Technology and Equipment of Food Production, 2, 11(110), 33-40 (in Ukrainian). doi: 10.15587/1729-4061.2021.230139 
23. Pinchuk, N.V., \& Kovalenko, T.M., (2021). Efektyvnist kontroliu chyselnosti brunkovoho smorodynovoho klishcha (Secidophyopsis ribis Westw.) u sortovykh ahrofitotsenozakh chornoi smorodyny, Silske hospodarstvo ta lisivnytstvo, 20, 139-155. doi: 10.37128/2707-5826-2021-11 (in Ukrainian).

24. Postolenko, L. V., (2016). Biolohichni osoblyvosti rozvytku smorodyny chornoi zalezhno vid vplyvu mulchuvannia gruntu. Visnyk NUVHP. Seriia «Silskohospodarski nauky», 3(75), 121-128 (in Ukrainian).

25. Pysarenko, V. M., Pysarenko, P. V., Ponomarenko, S. V., \& Shapoval, V. F. (2017). Orhanichne zemlerobstvo dlia pryvatnoho sektora / za red. V.M. Pysarenka. Poltava, 140 (in Ukrainian).

26. Sanchez-Hermosilla, J., Rincon, V. J., Paez, F. C., Perez-Alonso, J., \& Callejon-Ferre, A. J. (2021). Valuation of the Effect of Different Hand-Held Sprayer Types on a Greenhouse Pepper Crop, Agriculture-basel, 11(6), 532. doi: 10.3390/ agriculture11060532.

27. Suchkova, V. M., \& Morhun, O. V. (2015). Ekolohichni problemy plodovykh sadiv, Zakhyst i karantyn roslyn, 10, 8-9 (in Ukrainian).

28. Stepanova, N. A. (2018). Zaschita smorodinyi chYornoy ot vrediteley. Vestnik agrarnoy nauki, 5 (74), 104-108 (in Russian). doi: 10.152171/48484

29. Vityaz, S. N., \& Golovina, E. A. (2015). Primenenie ekologicheski bezopasnyih sredstv dlya kontrolya chislennosti fitofagov chYornoy smorodinyi v usloviyah Kemerovskoy oblasti, Dostizhenie nauki i tehniki APK, 29, 49-51 (in Russian).

30. Voitiuk, V. M. Baranovskyi, V. M. \& Bulhakov, D. H. (2005). Silskohospodarski mashyny. Osnovy teorii ta rozrakhunku. Vyshcha osvita, Kyiv, 464 (in Ukrainian).

31. Zaika, P. M. (2002). Teoriia silskohospodarskykh mashyn: navch. posibnyk // T. 1 : Mashyny dlia zakhystu roslyn vid shkidnykiv i khvorob. OKO, Kharkiv, 272 (in Ukrainian).

32. Zhidehina, T. V., Rodyukova, O. S., \& Gureva, I. V. (2017). Vliyanie bio-i abioticheskih faktorov sredyi na produktivnost smorodinyi chernoy. Dostizhenie nauki i tehniki APK, 31, 68-71 (in Russian).

Bakalova A. V., PhD (Agricultural Sciences), Associate Professor, Polissya National University, Zhytomyr, Ukraine

Gritsyuk N. V., PhD (Agricultural Sciences), Associate Professor of Plant Protection Department, Polissya National University, Zhytomyr, Ukraine

Tytarenko V. Y., PhD (Technical Sciences), Associate Professor, Zhytomyr Polytechnic State University, Zhytomyr, Ukraine Upgrading of OP-2000 sprayer for protection of black currants against sucking pests

Due to its taste, dietary, vitamin and consumer qualities, black currant is quite common crop for many farms and backyards. But unfortunately, like many other crops, it is prone to disease and pest damage, especially by pests with a prickly-sucking mouth apparatus. Therefore, the protection technology of black currants is currently a topical issue.

The authors of the research propose the use of an upgraded OP-2000 sprayer with the improved features of special structural moving parts, for better efficiency of black currant bushes spraying. It was proved that the density of sucking phytophages decreased when sprayed with modernized, updated OP-2000 sprayer. Accordingly, the population rate of large currant aphid decreased by 0.34 , redcurrant head aphid by 0.36 , currant bud mite by 0.29 and common spider mite by 0.23 units compared to the use of OP-2000 rod sprayer.

Researchers found out that the reduction in the number of sucking pests on blackcurrant plants had a positive effect on the formation of berries, and on an increase in the weight of 1000 berries, as well as on the weight of berries from the bush, which increased yields by 2.9 tha compared to the control version and 0.6 tha compared to the variant where a rod sprayer was used. The use of the device with special structural moving parts for the modernization of the OP-2000 sprayer provided an increase in economic efficiency. Thus, the net profit when using upgraded OP-2000 sprayer was UAH 63459-69587 /ha, profitability 350-362 \%. When using the upgraded sprayer, the net profit increased by UAH 6128 per hectare, the profitability of the harvest by $12 \%$ compared to the use of a rod sprayer. Research data on the creation of special moving parts (SMP) was conducted for the first time and may be continued with further improved designs of the protection system of berry crops from pests.

Key words: black currant, sucking phytophages, upgraded sprayer, productivity indicators, special structural moving parts. 